Zamina Aliyeva,

Baku State University, Azerbaijan Republic

iD ORCID ID 0000-0003-2693-0057,

email: zaminaaliyeva110@gmail.com

Correspondence author: zaminaaliyeva110@gmail.com

\title{
THE LAW ASPECTS IN HEALTH MANAGEMENT: A BIBLIOMETRIC ANALYSIS OF ISSUES ON THE INJURY, DAMAGE AND HARM IN CRIMINAL LAW
}

\begin{abstract}
The paper presents the analysis of the approaches to define the areas of research on the injury, damage and harm to human health in criminal law. The obtained results proved that crimes, connected to drugs abuse, their legislation become an essential part of the issues. At the same, developing of government control, medical standards, improving quality of medical education balancing the «medical mistake - injury to human's health jurisprudence consequences» triangle in the tendency of the injury, damage and harm in criminal law are becoming very important to the healthcare system due to increasing requirements of regulators, customers and shareholders. The paper aimed to analyse the tendency in the literature on the injury, damage and harm in criminal law, which published in books, journals, conference proceedings etc. to identify future research directions. The methodological tools are VOSviewer, Scopus and Web of Science (WoS) software. This study covers 1072 papers from Scopus and WoS database. The time for analysis were 1970-2020. The Scopus and WoS analyse showed that in 2012-2019 the numbers of papers on the injury, damage and harm in criminal law issues began to increase. However, the topics changed from general issues to the problem of decriminalisation of drug trafficking, and the corresponding paradigm shift in the punishment of some crimes, increasing interest in punishing corporations for violating environmental regulations. In 2017 the number of documents dedicated to injury, damage and harm in criminal law was increased by $667 \%$ compared to 2012. The main subject areas of analyses of the injury, damage and harm in criminal law were the next: Law, Public environmental, occupational health, Criminology penology, Substance abuse, Psychiatry, Medicine. The biggest amount of investigations of the injury, damage and harm in criminal law was published by the scientists from the USA, United Kingdom, Australia and Canada. In 2019 such journals with high impact factor as International Journal of Drug Policy, International Journal of Law and Psychiatry, The Lancet etc. published the number of issues, which analysed of the injury, damage and harm to human health in criminal law. Such results proved that theme on the injury, damage and harm to human health in criminal law is actually in the ongoing trends of the modern jurisprudence and regulation. The findings from VOSviewer defined 6 clusters of the papers which analysed the injury, damage and harm to human health in criminal law from the different points of views. The first biggest cluster (with the biggest number of connections) merged the keywords as follows: criminal justice, law enforcement, public health, health care policy, harm reduction, drug legislation, drug and narcotic control, substance abuse, homelessness etc. The second significant cluster integrated the keywords as follows: criminal behaviour, crime victim, adolescent, violence, mental health, mental disease, prisoner, young people, rape, police etc. The third biggest cluster concentrated on criminal aspects of jurisprudence, criminal law, human right, legal liability, social control, government regulation etc. The obtained results allow concluding that balancing the triangles «medical mistakes - criminal education» and «drugs - criminal - justice» and «abortion - criminal - women/children» form an important part of the injury, damage and harm in criminal law issues.
\end{abstract}

Keywords: injury, damage, harm, human health, criminal law, management, governance.

Introduction. A wave of protests in the United States following the death of 46-year-old African American George Floyd, who was strangled in detention by a white police officer, brings the attention of the scientific, legal field back to the issues injury, damage and harm to human health in criminal law. The criminology terminology on human health harm started to appear more frequently in the articles (not only scientific) after the publication of the World Health Organization Guidelines for the decriminalisation of

Cite as: Aliyeva, Z. (2020). The Law Aspects in Health Management: A Bibliometric Analysis of Issues on the Injury, Damage and Harm in Criminal Law. Marketing and Management of Innovations, 3, 293-305. http://doi.org/10.21272/mmi.2020.3-21 
Z., Aliyeva. The Law Aspects in Health Management: A Bibliometric Analysis of Issues on the Injury, Damage and Harm in Criminal Law

illicit drugs and to impose stricter requirements on the quality of food, children's toys and other household items aimed at the use of safe chemical compounds in many countries. This paper dedicated to a literature review regarding the use and the connections of keywords of terminology in the area of the injury, damage and harm to human health in criminal law issues. The goals of our paper are the next: 1) to summarise the level and spheres of knowledge of the injury, damage and harm to human health in criminal law; 2) to correlate published material dedicated to the injury, damage and harm to human health to answer the question regarding that terminology have strong connections with criminal law; 3 ) to identify the areas and features of injury, damage and harm to human health in criminal law; 4) to define untraditional spheres of the subject of injury, hurt and harm to human health, especially health and environmental safety. The Hammurabi Code presented the first mention of punishments against crimes to human's health. Despite that, the huge range of modern scientists in injuries, hurt and harm to human health, do so in the context of drug addiction, permitting or prohibiting abortions, medical errors, etc. For managing the goals, the articles published in Clarivates, ScienceDirect, Scopus or Web of Sciences were used. Finally, the paper proposes that one of the most unstudied areas of research, which can be ought to analyses in a future study, is the link between the injury, damage and harm to human health, inflicted by medical mistakes, in criminal law.

Literature review. The widespread use of law terminology of injury, damage or harm to human health in academic literature is linked recently with the requirement of law codex or pandect. The oldest publication, according to Scopus database, what can be found is paper (High Court of appeals, 1963), was published in 1963. It reveals the essence of the case concerning the complaint on the disclosure of the client's private medical information in the criminal trial of injury by a doctor. The Court used the principle that the public interest in punishing of criminal acts takes precedence over the complainant's claim to the safeguarding of her privacy. A separate area of research is the criminalisation of drug trafficking and consumption and related offences. The first work according to Scopus database was published in 1973 (Ingersoll,1973) and examines the effectiveness of measures to prevent drug abuse that can be applied in the United States, especially their social and political losses, the relationship with the values of society. In 1994, the first paper on the investigated theme indexed was published in the WoS database (GarrityRokous, 1994). It focused on reviewing the case law criminal and civil legal sanctions to deter drug use and to protect fetal health, statutory and constitutional difficulties, what limit the effectiveness of these sanctions and inhibit their applicability. The last paper in this area according to Scopus is the second edition of the book (Babor et al., 2019), that explored non-medical use of prescription medications and illicit drug use a public health system perspective, analysed the development of drug policy at different (local, national and international) levels in five its areas: 1) primary prevention programs in schools; 2) treatment interventions and harm reduction approach; 3) law enforcement, drug interdiction and control of the supply of illicit drugs; 4) decriminalisation and other penalty alternatives; 5) control of the legal market through prescription drug regimens. It made conclusions about effective and ineffective policies. Concerning WoS database, the last paper in this area is dedicated to analysing the result of the implementation of the Diversion Alert Program using trends in drug arrests and differences in arrests by offence, demographics (sex and age) and by region.

A large volume of publications is devoted to the legal aspects of abortion, the corresponding harm to maternal health, etc. The first work, according to Scopus database, was published in 1970 (Stamm,1970), which discussed aspects of legal and illegal abortion in Switzerland. The first paper (Harris and Grossman 2020) investigated the ordinary course of self-managed, medication-induced abortion and its rare complications. Besides, it considered the difficulties of unsafe methods when abortion laws become more restrictive, and women would end pregnancies without clinical supervision. According to WoS, the oldest article is paper (Surjadjaja, 2008). It analysed the policy of abortion in Indonesia. The newest one paper (Dyer et al., 2019), that identified associations between parish-level (county equivalent) prevalence of jail 
Z., Aliyeva. The Law Aspects in Health Management: A Bibliometric Analysis of Issues on the Injury, Damage and Harm in Criminal Law

incarceration within the black population and adverse birth outcomes among non-Hispanic black women in Louisiana in 2014. The next area of publications is damage to human health caused by environmental pollution or harmful substances and the corresponding criminal penalties. In Scopus, the first work (Magaldi, 1983) aimed at the criminal and tortious liability of manufacturers and sellers of machines and equipment whose noise levels were harmful to those who use them. In turn, the latest study (Johnson et al., 2020) in Scopus provided a unique dataset on virtually all federal criminal prosecutions of pollutionrelated offences between 1985 and 2010 used to assess aggregate trends in characteristics of pollution violations, offenders, and sanctions. According to WoS the oldest article (Castle, 1995) in this sphere is dedicated to health safety and environmental liabilities of the «nuclear industry», which divided into 3 areas: criminal liability for regulatory non-compliance; civil liability for damage caused to persons and their property (for example, neighbours, employees etc.); and environmental responsibility that may be incurred as a result of powers of the regulatory authorities to clean up contamination and to recoup the cost. Among recent - article (Vakula et al., 2019) analysed provisions of the criminal and administrative laws of the Russian Federation on liability for air pollution using the formal-legal method.

Another sphere of research is medical mistakes and criminal consequences. The oldest article in this area indexed by Scopus database (Heinen, 1973) dealt with the case of a gas-gangrene abscess of the brain with a presumed minor injury of the scalp medico-legal problems in criminal trial and issues of the missing of objective statements and data due to insufficiently made, delayed inquiries or uncompleted medical reports impedes expert's opinion on the actual case. Among recent paper - article (Grishina et al., 2019), where authors explain the consequences of inadequate or untimely medical care, which can lead to irreversible consequences for the patient: the transition of the disease to a chronic form, disability and even death, an appeal to various state bodies (departmental, judicial and law enforcement) with a request to investigate the event, certainly to find and punish the perpetrators, and ways of objective resolution of such disputes. According to WoS, the oldest paper (Bucy, 1995). In this article, Professor Pamela $\mathrm{H}$. Bucy addresses the issues surrounding crimes committed by health care providers and argues in favour of more aggressive prosecution of those who commit health care fraud, current legislative efforts to curb abuses in the health care system, and offers suggestions as to how these proposed laws may be effectively implemented to achieve their purpose and propose several additional reforms to federal and state criminal statutes, reforms which she believes have needed to combat health care crimes in the future. The latest paper (Vuletic, 2019) dedicated to a comparative overview of the criminalisation of medical errors in Europe shows that this is approached in two ways: 1) such errors are incriminated through the general regime for criminal offences, such as bodily injury or causing death by negligence; 2) adopted in a smaller number of countries, prescribes it as a separate criminal offence (as medical malpractice). The author analysed the Croatian legislative solution and its realisation in judicial practice. Based on that analysis, through the presentation of noteworthy case law, it provides conclusions on whether or not the Croatian legislative solution indeed provides a higher degree of protection of the health of patients and a higher level of legal certainty. The data proved that there are a large number of studies on injuries, damage and harm to human health in criminal law, both from the standpoint of environmental offences and from hooliganism or more serious personal crimes. However, this problem has not yet been analysed, taking into account various aspects of the health care system, medical errors, medical standards and protocols. In this case, the purpose of the article was to analyse the tendency in the scientific literature on harm to human health in criminal law to determine future areas of research.

Methodology and research methods. The main hypothesis of investigation is cheeking the increasing tendency on analysing of injury, damage and harm to humans health in criminal law issues by the scientists. For this purpose, according to paper (Vasylieva et al., 2020), this paper provides the analysis in the same sequence and with emphasis on the same aspects and scheme: 
Z., Aliyeva. The Law Aspects in Health Management: A Bibliometric Analysis of Issues on the Injury, Damage and Harm in Criminal Law

1. Using Scopus and WoS tools, the study defined the quantity trends of the publishing of papers, which focused on the analyses of injury, damage and harm to humans' health in criminal law issues.

2. Allocating the main subject areas under analyses of injury, damage and harm to humans' health in criminal law issues.

3. Identifying the most citation papers and Journals, which contained the papers on the injury, damage and harm to humans health in criminal law.

4. Clustering the papers on the main directions for investigations with the purpose to identify the further options for analyses.

5. For the analysis, the following keywords were chosen: injury, damage, harm, humans' health, criminal law. This study reviewed the simple of 1072 papers from Scopus and Web of Science.

The period for analysis was 1970-2020 (all timeline of WoS indexing of publications). The analyse was conducted by using tools of the software of VOSviewer, WoS and Scopus. Using Scopus and WoS tools, there was analysed the publications under the next parameters: journal, citation, number of the papers, the subject area and country affiliation. VOSviewer software allowed allocating and visualising the network of keywords which used in issues during the investigation of injury, damage and harm to humans health in criminal law and the scientific directions which has strong relationships. It should be noted that, according to Vosviewer tools, the closer keywords are located to each other, the stronger their relations.

Results. Analysing proved that the numbers of paper which devoted to the injury, damage and harm to human's health in criminal law in the database Scopus has been gradually rising over the whole analysed period, with an average growth rate of $17 \%$. A similar situation is observed with the numbers of paper which focused on the injury, damage and harm to human's health in criminal law, which published in the journals, which are ranked by the WoS database. Thus this database shows the essential growth rate of publications from 2012 to 2017. The active discussion can interpret this among scientists and professionals of the difficulties of decriminalisation of drug trafficking, and the corresponding paradigm shift in the punishment of some crimes, increasing interest in punishing corporations for violating environmental regulations, and so on. As a result, in 2019, the number of articles dedicated to injury, damage and harm to humans health in criminal law increased by $667 \%$ compared to 2012 (Figure 1).

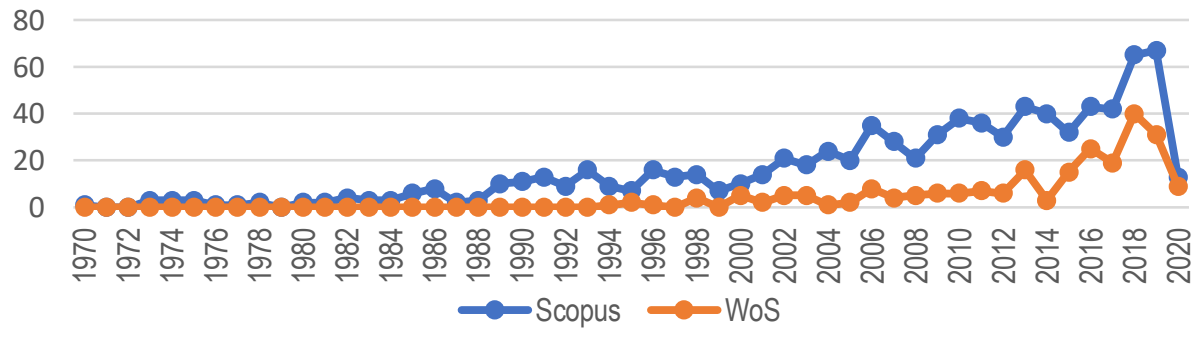

Figure 1. The number of documents in Scopus and WoS which contain the injury, damage and harm to human's health in criminal law issues

Sources: developed by the authors.

The findings demonstrated that the injury, damage and harm to human's health in criminal law was analysed according to data of Scopus in the framework of the subject area as follows: Medicine $-56,51 \%$; Social science - 18,44\%; Psychology - 6,68\%; Nursing - 4,57\%; and others (Decision Sciences, Multidisciplinary, Economics, Econometrics and Finance, Business, Management and Accounting etc.) $5,33 \%$ (Figure 2). 
Z., Aliyeva. The Law Aspects in Health Management: A Bibliometric Analysis of Issues on the Injury, Damage and Harm in Criminal Law

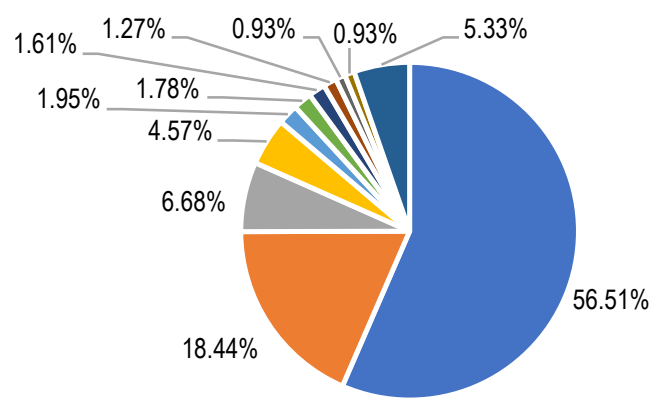

\author{
- Medicine \\ - Social Sciences \\ - Psychology \\ $\square$ Nursing \\ - Arts and Humanities \\ - Pharmacology, Toxicology and \\ Pharmaceutics \\ - Environmental Science
}

Figure 2. The subject area in Scopus for analysing the injury, damage and harm to human's health in criminal law issues

Sources: developed by the authors.

According to data of WoS, in the framework of the subject area the injury, damage and harm to humans health in criminal law was analysed as follows: Law - 15,85\%; Public environmental, occupational health -9,45\%; Criminology penology - 8,84\%; Substance abuse - 6,1\%; Psychiatry - 5,79\%; Medicine general internal - 5,18\%; Ethics - 2,44 and others (Multidisciplinary Sciences, Economics, Business, Finance, Development Studies etc.) - 31,71\% (Figure 3).

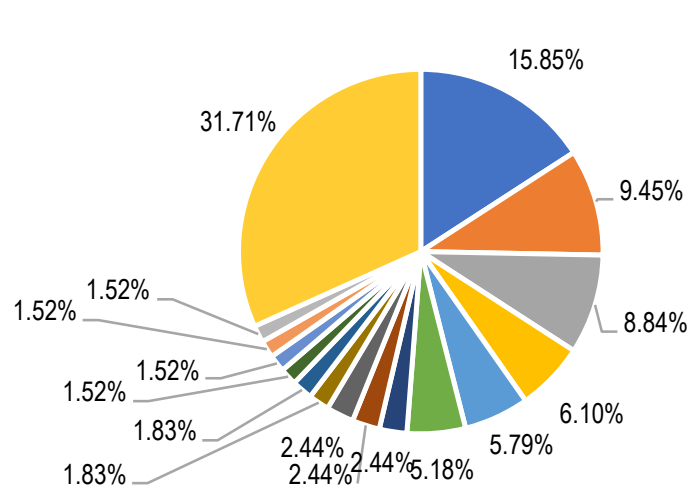

$$
\begin{aligned}
& \text { - Law } \\
& \text { - Public environmental occupational } \\
& \text { - Crealth } \\
& \text { - Criminology penology } \\
& \text { - Substance abuse } \\
& \text { - Psychiatry } \\
& \text { - Medicine general internal } \\
& \text { - Ethics } \\
& \text { - Social sciences biomedical } \\
& \text { - Social sciences interdisciplinar }
\end{aligned}
$$

Figure 3. The subject area in WoS for analysing the injury, damage and harm to human's health in criminal law issues

Sources: developed by the authors.

The analysis of authors' affiliations by country showed that the vast majority the scientists, investigated the injury, damage and harm to humans health in criminal law, were from the USA, United Kingdom, Australia and Canada affiliations. The top 20 countries' affiliation of the scientists which investigated the injury, damage and harm to humans health in criminal law issues according to Scopus database showed in Figure 4. It also shows the number of publications from these countries in the WoS database. Besides, considering the findings from Scopus in 2019 the high ranked International Journal of Drug Policy, International Journal of Law and Psychiatry, The Lancet began to publish more papers on the injury, damage and harm to humans health in criminal law issues (Table 1). 
Z., Aliyeva. The Law Aspects in Health Management: A Bibliometric Analysis of Issues on the Injury, Damage and Harm in Criminal Law

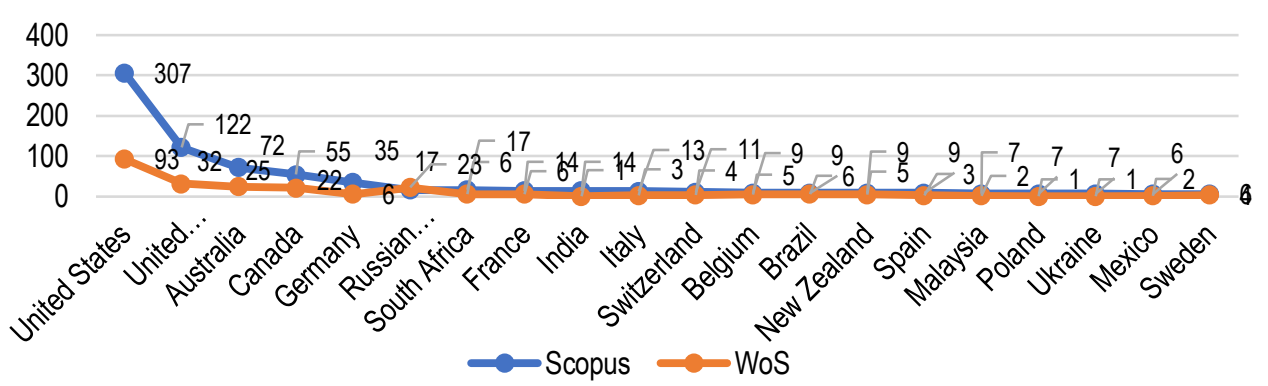

Figure 4. Top 20 country's affiliation of the scientists which investigated the injury, damage and harm to human's health in criminal law issues

Sources: developed by the authors.

Table 1. The top 5 Journal, indexed by Scopus, which published the papers on the injury, damage and harm to humans health in criminal law

\begin{tabular}{|c|c|c|c|c|c|}
\hline Title of the Journal & $\begin{array}{l}\text { Covered by } \\
\text { Scopus }\end{array}$ & $\begin{array}{l}\text { CiteScore } \\
2019\end{array}$ & $\begin{array}{l}\text { SJR } \\
2019\end{array}$ & $\begin{array}{l}\text { SNIP } \\
2019\end{array}$ & $\begin{array}{c}\text { Numbers of the } \\
\text { papers }\end{array}$ \\
\hline International Journal of Drug Policy & 1998 to 2020 & 6.0 & 1.605 & 1.395 & 33 \\
\hline $\begin{array}{l}\text { International Journal of Law and } \\
\text { Psychiatry }\end{array}$ & $\begin{array}{l}1978 \text { to } 1984,1986 \\
\text { to } 2020\end{array}$ & 2.3 & 0.509 & 0.956 & 14 \\
\hline $\begin{array}{l}\text { Journal of the American Academy of } \\
\text { Psychiatry and the Law }\end{array}$ & 1997 to 2020 & 1.5 & 0.330 & 0.706 & 9 \\
\hline The Lancet & 1823 to 2020 & 73.4 & 14.554 & 21.313 & 9 \\
\hline Medicine and Law & 1982 to 2020 & 0.4 & 0.163 & 0.153 & 8 \\
\hline
\end{tabular}

Sources: developed by the authors.

Table 2. The top 5 Journal, indexed by WoS, which published the papers on the injury, damage

\begin{tabular}{|c|c|c|c|c|c|}
\hline \multirow[b]{2}{*}{ Title of the Journal } & \multicolumn{3}{|c|}{ narm to human's health in criminal law } & \multirow[b]{2}{*}{$\begin{array}{l}\text { Quartile in } \\
\text { Category }\end{array}$} & \multirow[b]{2}{*}{$\begin{array}{l}\text { Numbers of } \\
\text { the papers }\end{array}$} \\
\hline & $\begin{array}{c}\mathrm{H} \\
\text { Index }\end{array}$ & Quartiles & $\begin{array}{l}\text { SJR } \\
2019\end{array}$ & & \\
\hline $\begin{array}{lll}\text { International Journal Of } \\
\text { Drug Policy }\end{array}$ & 72 & $\begin{array}{l}\text { Health Policy; Medicine } \\
\text { (miscellaneous) }\end{array}$ & 1,605 & Q1 & 12 \\
\hline $\begin{array}{l}\text { Russian Journal of } \\
\text { Criminology }\end{array}$ & 7 & $\begin{array}{c}\text { Law } \\
\text { Sociology and Political science }\end{array}$ & 0,243 & $\begin{array}{l}\text { Q2 } \\
\text { Q3 }\end{array}$ & 9 \\
\hline $\begin{array}{l}\text { Tomsk state university } \\
\text { journal }\end{array}$ & - & - & - & - & 4 \\
\hline $\begin{array}{l}\text { Journal Of The American } \\
\text { Academy Of Psychiatry And } \\
\text { The Law }\end{array}$ & 53 & $\begin{array}{l}\text { Pathology and Forensic medicine; } \\
\text { Psychiatry and Mental Health }\end{array}$ & 0,33 & Q3 & 4 \\
\hline $\begin{array}{l}\text { MMWR Surveillance } \\
\text { summaries }\end{array}$ & 0.91 & $\begin{array}{l}\text { Epidemiology; Health information } \\
\text { management; Health (social science) } \\
\text { Health, Toxicology and Mutagenesis }\end{array}$ & 20,617 & Q1 & 3 \\
\hline
\end{tabular}

Sources: developed by the authors.

According to the Scopus database all 10 the most cited papers were published by the high ranked Journals. The most cited papers were published by the scientists Patton et al. (2016) in the high-rank journal The Lancet (Table 3). The same situation is in the WoS database -10 most cited papers were presented in the high ranked journals (Table 2). 
Z., Aliyeva. The Law Aspects in Health Management: A Bibliometric Analysis of Issues on the Injury, Damage and Harm in Criminal Law

In 2010, a famous criminologist and Senior Research Fellow at the National Drug and Alcohol Research Centre of Australia, and Vice-President of the International Society for the Study of Drug Policy Caitlin Hughes published the paper «What can we learn from the Portuguese decriminalisation of illicit drugs?». That article had 161 citations in the Scopus database and 136 - in the WoS database. In this paper, the authors examined the Portugal case of with decriminalised the use and possession of all illicit drugs. Besides, they critically analysed the criminal justice and health impacts against trends from neighbouring Spain and Italy. It concludes that contrary to predictions, the Portuguese decriminalisation did not lead to major increases in drug use. Indeed, evidence indicates reductions in problematic use, drug-related harms and criminal justice overcrowding.

Table 3. The most cited papers on the injury, damage and harm to human's health in criminal law 1970-2020 according to Scopus database

\begin{tabular}{|c|c|c|c|}
\hline Authors and Title & Year & Source title & Cited \\
\hline $\begin{array}{l}\text { Patton, G. C., Sawyer, S. M., Santelli, J. S. et al. Our future: } \\
\text { a Lancet commission on adolescent health and wellbeing }\end{array}$ & 2016 & The Lancet & 649 \\
\hline $\begin{array}{l}\text { Florence, C. S., Zhou, C., Luo, F., Xu, L. The economic } \\
\text { burden of prescription opioid overdose, abuse, and } \\
\text { dependence in the United States, } 2013\end{array}$ & 2016 & Medical Care & 374 \\
\hline Marlatt, G. A. Harm reduction: Come as you are & 1996 & Addictive Behaviors & 204 \\
\hline $\begin{array}{l}\text { Hughes, C. E., Stevens, A. What can we learn from the } \\
\text { Portuguese decriminalisation of illicit drugs? }\end{array}$ & 2010 & $\begin{array}{l}\text { British Journal of } \\
\text { Criminology }\end{array}$ & 161 \\
\hline $\begin{array}{l}\text { Hawkins, K. Law as Last Resort: Prosecution Decision- } \\
\text { Making in a Regulatory Agency }\end{array}$ & 2010 & $\begin{array}{l}\text { Law as Last Resort: } \\
\text { Prosecution Decision- } \\
\text { Making in a Regulatory } \\
\text { Agency }\end{array}$ & 155 \\
\hline $\begin{array}{l}\text { Buckholtz, J. W., Marois, R. The roots of modern justice: } \\
\text { Cognitive and neural foundations of social norms and their } \\
\text { enforcement }\end{array}$ & 2012 & Nature Neuroscience & 139 \\
\hline $\begin{array}{l}\text { Martens, M. P., Pedersen, E. R., LaBrie, J. W., Ferrier, A. } \\
\text { G., Cimini, M. D. Measuring Alcohol-Related Protective } \\
\text { Behavioral Strategies Among College Students: Further } \\
\text { Examination of the Protective Behavioral Strategies Scale }\end{array}$ & 2007 & $\begin{array}{l}\text { Psychology of Addictive } \\
\text { Behaviors }\end{array}$ & 134 \\
\hline $\begin{array}{l}\text { Strang, J., Babor, T., Caulkins, J. et al. Drug policy and the } \\
\text { public good: Evidence for effective interventions }\end{array}$ & 2012 & The Lancet & 132 \\
\hline $\begin{array}{l}\text { Zimmerman, C., Hossain, M., Watts, C. Human trafficking } \\
\text { and health: A conceptual model to inform policy, intervention } \\
\text { and research }\end{array}$ & 2011 & $\begin{array}{l}\text { Social Science and } \\
\text { Medicine }\end{array}$ & 127 \\
\hline $\begin{array}{l}\text { Mossman, D., Noffsinger, S. G., Ash, P. et al. AAPL practice } \\
\text { guideline for the forensic psychiatric evaluation of } \\
\text { competence to stand trial }\end{array}$ & 2007 & $\begin{array}{c}\text { Journal of the American } \\
\text { Academy of Psychiatry and } \\
\text { the Law }\end{array}$ & 119 \\
\hline
\end{tabular}

Sources: developed by the authors.

The first biggest cluster (red cluster) merged the paper which contained the keywords as follows: criminal justice, law enforcement, public health, health care policy, harm reduction, drug legislation, drug and narcotic control, substance abuse, homelessness etc. (Figure 6). The second biggest cluster (green cluster) contained such issues as follows: criminal behaviour, crime victim, adolescent, violence, mental health, mental disease, prisoner, young people, rape, police etc.

Table 4. The most cited papers on the injury, damage and harm to human's health in criminal law 1970-2020 according to WoS database 
Z., Aliyeva. The Law Aspects in Health Management: A Bibliometric Analysis of Issues on the Injury, Damage and Harm in Criminal Law

\begin{tabular}{|c|c|c|c|}
\hline Authors and Title & Year & Source title & Cited \\
\hline $\begin{array}{l}\text { Hughes, Caitlin Elizabeth; Stevens, Alex } \\
\text { What Can We Learn From The Portuguese } \\
\text { Decriminalisation of Illicit Drugs? }\end{array}$ & 2010 & $\begin{array}{l}\text { British Journal of } \\
\text { Criminology }\end{array}$ & 136 \\
\hline $\begin{array}{l}\text { Zimmerman, Cathy; Hossain, Mazeda; Watts, Charlotte. } \\
\text { Human trafficking and health: A conceptual model to inform } \\
\text { policy, intervention and research }\end{array}$ & 2011 & $\begin{array}{l}\text { Social Science \& } \\
\quad \text { Medicine }\end{array}$ & 110 \\
\hline $\begin{array}{l}\text { Hall, Wayne; Lynskey, Michael. Evaluating the } \\
\text { public health impacts of legalising recreational cannabis use } \\
\text { in the United States }\end{array}$ & 2016 & Addiction & 103 \\
\hline $\begin{array}{l}\text { Crume, T. L.; DiGuiseppi, C.; Byers, T.; et al. } \\
\text { Underascertainment of child maltreatment fatalities by death } \\
\text { certificates, 1990-1998 }\end{array}$ & 2002 & Paediatrics & 92 \\
\hline $\begin{array}{l}\text { Galletly, Carol L.; Pinkerton, Steven D. Conflicting } \\
\text { messages: How criminal HIV disclosure laws undermine } \\
\text { public health efforts to control the spread of HIV }\end{array}$ & 2006 & AIDS And Behavior & 74 \\
\hline 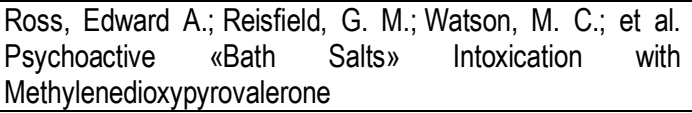 & 2012 & $\begin{array}{l}\text { American Journal of } \\
\text { Medicine }\end{array}$ & 72 \\
\hline $\begin{array}{l}\text { Rhodes, Tim; Platt, Lucy; Sarang, Anya; et al. Street } \\
\text { policing, injecting drug use and harm reduction in a Russian } \\
\text { city: A qualitative study of police perspectives }\end{array}$ & 2006 & $\begin{array}{l}\text { Journal of Urban Health- } \\
\text { bulletin of the New York } \\
\text { Academy of Medicine }\end{array}$ & 70 \\
\hline $\begin{array}{l}\text { Beletsky, L.; Macalino, G. E.; Burris, S. Attitudes of police } \\
\text { officers towards syringe access, occupational needle-sticks, } \\
\text { and drug use: A qualitative study of one city police } \\
\text { department in the United States }\end{array}$ & 2005 & $\begin{array}{l}\text { International Journal of } \\
\text { Drug Policy }\end{array}$ & 62 \\
\hline $\begin{array}{l}\text { Scorgie, Fiona; Vasey, Katie; Harper, Eric; et al. Human } \\
\text { rights abuses and collective resilience among sex workers } \\
\text { in four African countries: a qualitative study }\end{array}$ & 2013 & Globalisation and Health & 55 \\
\hline $\begin{array}{l}\text { Merry, A.F.; Peck, D.J. Anesthetists, errors in drug } \\
\text { administration and the law }\end{array}$ & 1995 & $\begin{array}{c}\text { New Zealand Medical } \\
\text { Journal }\end{array}$ & 54 \\
\hline
\end{tabular}

Sources: developed by the authors.

The findings from VOSviewer identified 6 clusters of the papers which investigated the injury, damage and harm to humans health in criminal law from the different points of views (Figure 5). The third biggest cluster (blue cluster) focused on jurisprudence, criminal law, human right, legal liability, social control, government regulation etc. The fourth-biggest cluster (the yellow one) merged the paper, which contained the keywords as follows: human, medical ethics, patient care, homicide, medical error, negligence, standard, legal aspect, clinical practice etc. Next cluster (purple) located close to the second one (green) and yellow cluster (medical mistake) contained such issues as follows: injury, forensic medicine, aetiology, education, major clinical study etc. They are connected through the word «study/education - medical standards- medical mistake - crime behaviour», «sex ratio - sex difference - risk factor» etc. The closer location of the abovementioned cluster to each other proved the stronger their relations. 
Z., Aliyeva. The Law Aspects in Health Management: A Bibliometric Analysis of Issues on the Injury, Damage and Harm in Criminal Law

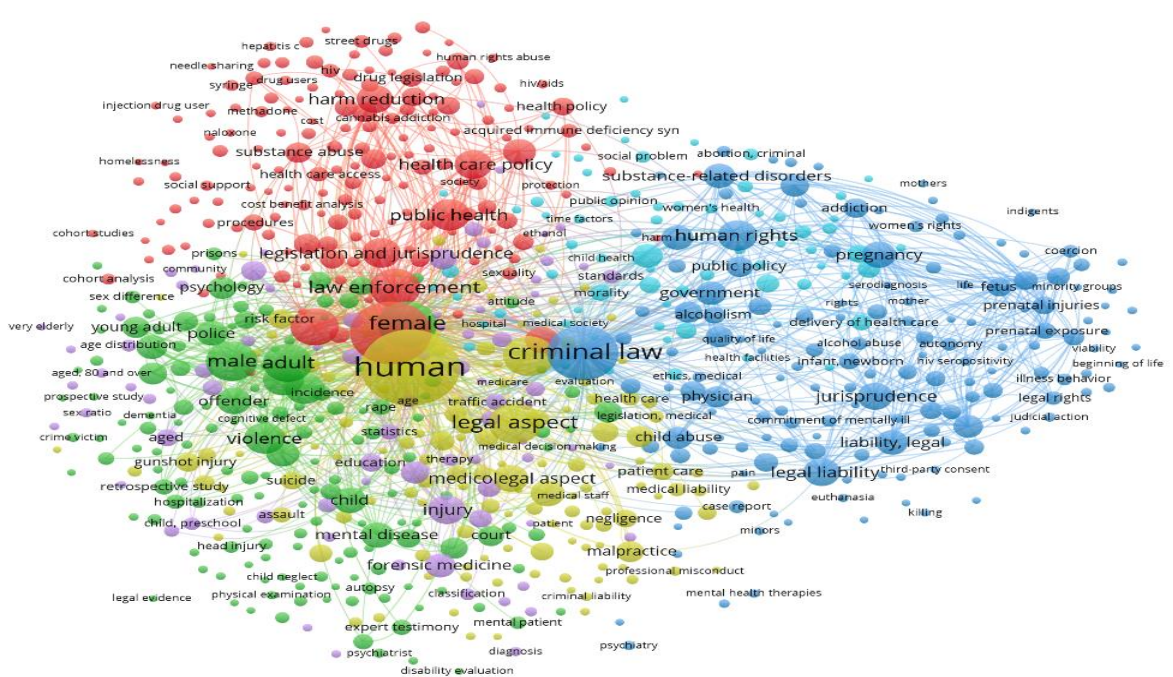

Figure 5. The network visualisation of the co-citation of the papers on the injury, damage and harm to human's health in criminal law

Sources: developed by the authors using the Scopus and WoS database and VOSviewer tool.

Such tendency allows concluding that education, study, school/preschool and violence among young people children are very close and popular in different issues. The findings proved that education becomes an important part of issues on the medical mistake (Figure 7).

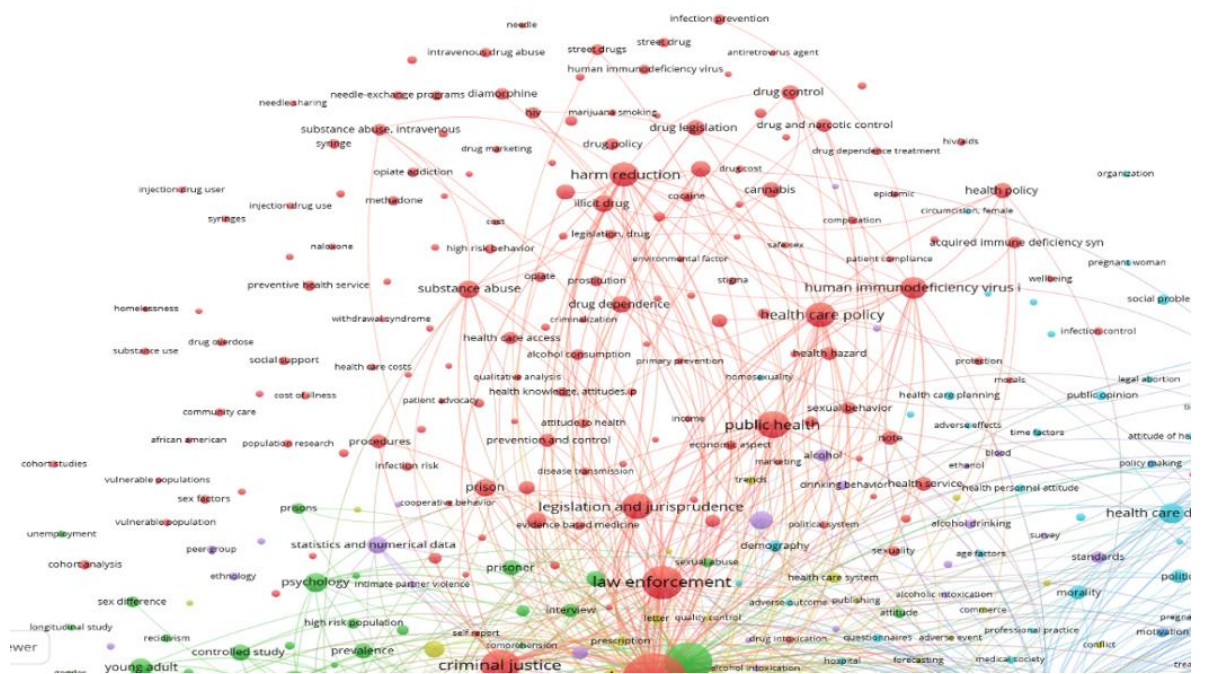

Figure 6. The network visualisation of the co-citation of the papers on the injury, damage and harm to human's health in criminal law with close areas (red cluster)

Sources: developed by the authors using the Scopus and WoS database and VOSviewer tool. 
Z., Aliyeva. The Law Aspects in Health Management: A Bibliometric Analysis of Issues on the Injury, Damage and Harm in Criminal Law

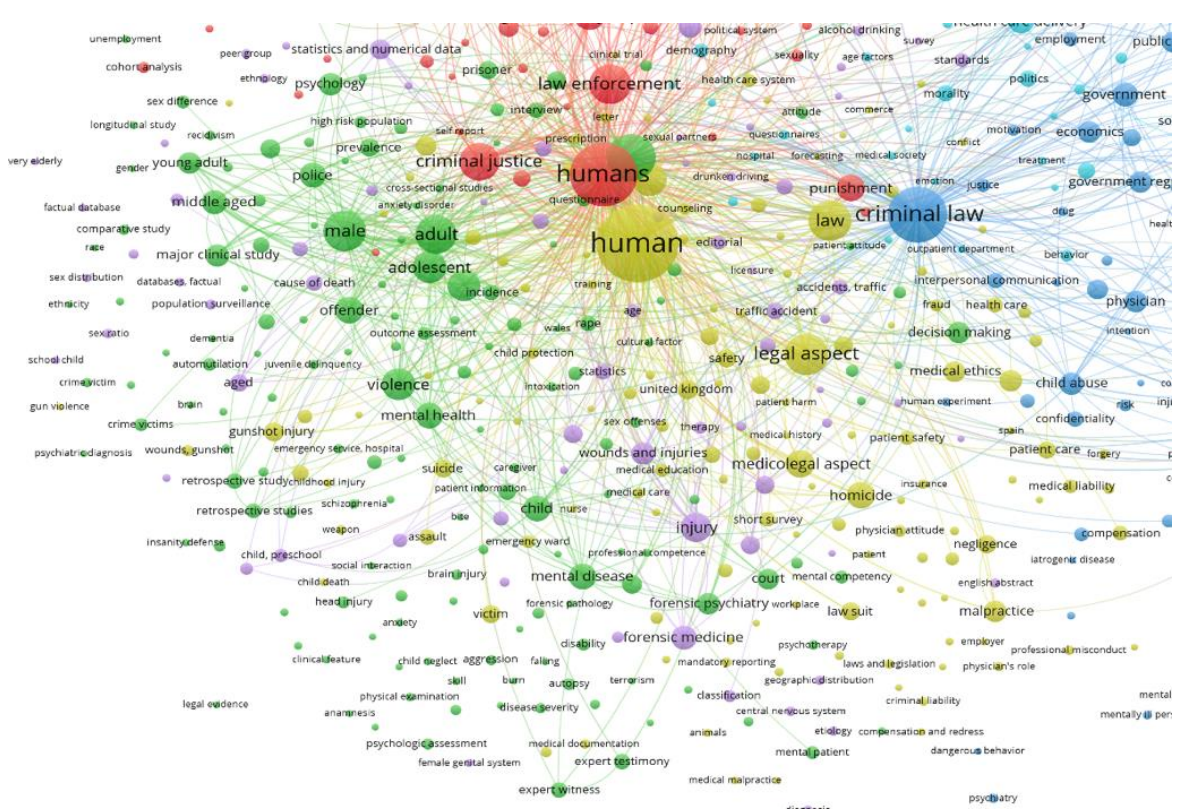

Figure 7. The network visualisation of the co-citation of the papers on the injury, damage and harm to human's health in criminal law with close areas (green and yellow clusters)

Sources: developed by the author using the Scopus and WoS database and VOSviewer tool.

Next small cluster turquoise (abortion and criminal). Noted, that turquoise clusters also located close to tow bigger clusters - red and blue ones. It allows concluding, that legislation of abort and injury to the health of woman and children in the attention of criminal law (Figure 8).

Thus, at the next stage, with the purpose to do a deep analysis of the co-citations on the injury, damage and harm to human's health in criminal law of the third and fourth-biggest clusters were analysed in detail. The keywords were chosen as follows: medical ethics, social control, confidentiality, government regulation. The findings showed in Figure 8. Thus, the findings proved the research hypothesis that the topic of the injury, as a result of medical negligence or error in criminal law in the papers which analysed the injury, damage and harm to human's health in criminal law issues are very popular.

The results showed 6 clusters. The biggest was red, green, blue and yellow. In this case, the red cluster contained keywords as follows: relating to offences related to drug use and distribution. Thus, the findings proved the research hypothesis that the topic of illicit drugs and results of their legislation in the papers which analysed the injury, damage and harm to human's health in criminal law issues are very popular. At the same time, the most related areas with the injury, damage and harm to human's health in criminal law were a medical mistake, abortion, violence, government control and justice. 
Z., Aliyeva. The Law Aspects in Health Management: A Bibliometric Analysis of Issues on the Injury, Damage and Harm in Criminal Law

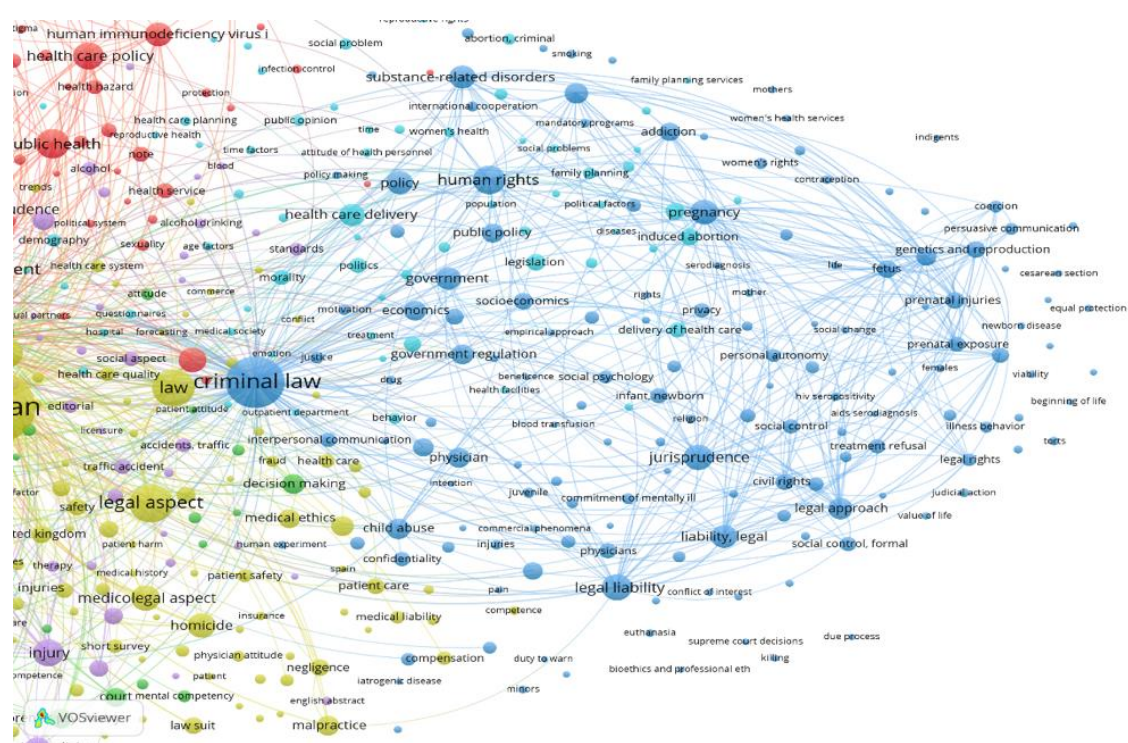

Figure 8. The network visualisation of the co-citation of the keywords on blue and yellow clusters Sources: developed by the authors using the Scopus and WoS database and VOSviewer tool.

Conclusion. The results of the analysis proved that injury, damage and harm to human's health in criminal law is a popular direction for investigation which formed in separate scientific school. Besides, the quantity of paper become increased from the 2012 year, that associated with the active discussion of the difficulties of decriminalisation of drug trafficking, and the corresponding paradigm shift in the punishment of some crimes, increasing interest in punishing corporations for violating environmental regulations. The findings from VOSviewer allow allocating 6 clusters, which have a close relationship. The first biggest cluster relating to offences related to drug use and distribution. The second biggest cluster merged the keywords as follows: criminal behaviour, crime victim, adolescent, violence, mental health, mental disease, prisoner, young people, rape, police etc. The third biggest cluster focused on criminal aspects of jurisprudence, criminal law, human right, legal liability, social control, government regulation etc. The fourth-biggest cluster (the yellow one) merged the paper which related to medical mistakes, negligence or error and their consequences. Such tendency allows concluding, that triangles «medical mistakes criminal - education» and «drugs - criminal - justice» and «abortion - criminal - women/children» become important parts of the topic - the injury, damage and harm to human's health in criminal law.

\section{References}

Babor, T. F., Caulkins, J., Fischer, B., Foxcroft, D., Medina-Mora, M. E., Obot, I., .. \& Strang, J. (2019). Drug Policy and the Public Good: a summary of the second edition. Addiction, 114(11), 1941-1950. [Google Scholar] [CrossRef]

Baranovskyi O. I., Khutorna M. E. Methodology of forming the system of ensuring financial stability of credit institutions. Financial and credit activities: problems of theory and practice. 2018. Vol. 4. No 27. P. 4-13. [Google Scholar] [CrossRef]

Bucy, P. H. (1995). Crimes by health care providers. University of Illinois law review, 3, 589-665. [Google Scholar]

Castle, P. (1995). Environmental issues and the nuclear industry. Energy policy, 23(2), 139-147. [Google Scholar] [Google Scholar]

Dzwigol, H., Dzwigol-Barosz, M., Miskiewicz, R., \& Kwilinski, A. (2020). Manager Competency Assessment Model in the Conditions of Industry 4.0. Entrepreneurship and Sustainability Issues, 7(4), 2630-2644. [Google Scholar] [CrossRef] 
Z., Aliyeva. The Law Aspects in Health Management: A Bibliometric Analysis of Issues on the Injury, Damage and Harm in Criminal Law

Dźwigoł, H., \& Dźwigoł-Barosz, M. (2018). Scientific Research Methodology in Management Sciences. Financial and Credit Activity: Problems of Theory and Practice, 2(25), 242-237. [Google Scholar] [CrossRef]

Dyer, L., Hardeman, R., Vilda, D., Theall, K., \& Wallace, M. (2019). Mass incarceration and public health: the association between black jail incarceration and adverse birth outcomes among black women in Louisiana. BMC Pregnancy and Childbirth, 19(1), 525. [Google Scholar] [CrossRef]

Garrity-Rokous, F. E. (1994). Punitive legal approaches to the problem of prenatal drug exposure. Infant mental health journal, 15(2), 218-237. [Google Scholar] [CrossRef]

Grishina, E. P., Shiryaeva, S. V., Sheiafetdinova, N. A., \& Solovyev, A. A. (2019). Forensic Medical Examination of the Quality of Medical Care: Legal, Methodological and Ethical Issues. International Journal of Psychosocial Rehabilitation, 23(4). [Google Scholar]

Harris, L. H., \& Grossman, D. (2020). Complications of unsafe and self-managed abortion. New England Journal of Medicine, 382(11), 1029-1040. [Google Scholar] [CrossRef]

Heinen, M. (1973). Gas-gangrene abscess of the brain after «minor injuries» of the head (author's transl). Zeitschrift fur Rechtsmedizin. Journal of legal medicine, 73(3), 245. [Google Scholar]

High Court of appeals. Celle 23. A. on the question of permissability of confiscation of the medical records. B. on the criminal nature of nonmedically indicated sterilisations. (1963). Neue Juristische Wochenschrift, 16, 406-408. Retrieved from www.scopus.com.

Hughes, C. E., \& Stevens, A. (2010).What Can We Learn from the Portuguese Decriminalisation of Illicit Drugs? British Journal of Criminology, 50(6), 999-1022. [CrossRef]

Ingersoll, J. E. (1973). Prevention: A law-enforcement point of view. Preventive medicine, 2(4), 561-568. [Google Scholar] [CrossRef

Johnson, E. W., Schwartz, J., \& Inlow, A. R. (2020). The criminalisation of environmental harm: a study of the most serious environmental offenses prosecuted by the US federal government, 1985-2010. Environmental Sociology, 1-15. [Google Scholar] [CrossRef]

Kuzior, A., Kwilinski, A., \& Tkachenko, V. (2019). Sustainable development of organizations based on the combinatorial model of artificial intelligence. Entrepreneurship and Sustainability, 7(2), 1353-1376. [Google Scholar] [CrossRef]

Kwilinski, A., Vyshnevskyi, O., \& Dzwigol, H. (2020). Digitalization of the EU Economies and People at Risk of Poverty or Socia Exclusion. Journal of Risk and Financial Management, 13(7), 142. [Google Scholar] [CrossRef]

Magaldi, R. (1983). Factory Noise. Minerva Medica, Sep 8, 74(34), 1949-1953.

Patton, G. C., Sawyer, S. M., Santelli, J. S... \& Viner, R. M. (2016). Our future: A lancet commission on adolescent health and wellbeing. The Lancet, 387(10036), 2423-2478. [CrossRef]

Stamm, H. (1970). Legal and illegal abortion in Switzerland. Fortschritte der Geburtshiffe und Gynakologie, 42, 1. [Google Scholar]

Surjadjaja, C. (2008). Policy Analysis of Abortion in Indonesia: The Dynamic of State Power, Human Need and Women's Right. IDS bulletin, 39(3), 62-71. [Google Scholar] [CrossRef]

The Code of Hammurabi. Retrieved from https://avalon.law.yale.edu/ancient/hamframe.asp.

Vakula M. A., Dobryakov D. A., \& Minyazeva T. F. (2019). Issues of Liability for Air Pollution Under the Criminal and Administrative Laws of Russia. Tomsk State University Journal, 447, 222-231. [Google Scholar] [CrossRef]

Vasylieva, T., Bilan, Y., Starchenko, L., \& Woźniak, A. (2020) Green Intellectual capital for sustainable business model: bibliometric analysis. In Proceedings of the 34th International Business Information Management Association (IBIMA) conference. Retrieved from https://ibima.org/conference/35th-ibima-conference/

Vuletic, I. (2019). Medical Malpractice as a Separate Criminal Offense: a Higher Degree of Patient Protection or Merely a Sword Above the Doctors' Heads? The Example of the Croatian Legislative Model and the Experiences of its Implementation. Medicine, Law \& Society, 12(2), 39-60. [Google Scholar]

Заміна Алієва, Бакинський державний університет, Азербайджанська Республіка

Правові аспекти в управлінні охороною здоров'я: бібліометричний аналіз

у статті проаналізовано наукові напрями вивчення проблематик щоло травмування, збитків та шкоди здоров'ю суспільсву з точки зору кримінального права. Систематизація літературних напрацювань свідчить про зростаючий інтерес світової науковової спільноти до аналізу злочинів, пов'язаних зі зловживанням наркотиками та їх легалізацією. У той же час, розвиток державного контролю, підвищення медичних стандартів та якості медичної освіти, що забезпечують баланс у трикутнику «медична помилка - школа здоров'ю людини - юридичні наслідки» стають більш важливими в управлінні охороною здоров'я. Головною метою статті $є$ визначення майбутніх напрямків досліджень на основі аналізу тенденції наукових напрацювань щодо питань травмування, збитків та шкоди у кримінальному праві. Детермінованою вибіркою дослідження є 1072 публікації (книги, журнали, матеріали конференцій, тощо) представлені у наковометричних базах даних Scopus ta Web of Science. Емпіричне дослідження проведено з використанням інструментарію програмного забезпечення VOSviewer, Scopus and Web of Science. Періодом дослідження обрано 1970-2020 роки. Отримані результати свідчать, що у 2012-2019 роках, кількість публікацій на тему травмування, збитків та шкоди почала зростати у базі даних Scopus. Однак, згодом загальна тематика почала змінюватись до дослідження питань декриміналізації торгівлі наркотиками, зміни 
Z., Aliyeva. The Law Aspects in Health Management: A Bibliometric Analysis of Issues on the Injury, Damage and Harm in Criminal Law

парадигми покарання за скоєння певних злочинів та покарання корпорацій за порушення екологічних норм. Автори зазначили, що у 2017 кількість публікацій з досліджуваної тематики збільшилась на 667\% порівняно до 2012 року. Встановлено, що основними науковими напрямами є: закон, громадська гігієна праці, кримінальна пенологія, токсикоманія, психіатрія, медицина. Найбільша частка науковців, які досліджували питання травмування, збитків та шкоди в кримінальному законодавстві, були з США, Великобританії, Австралії та Канади. Автори відмітили, що у 2019 році значно зросла кількість публікацій у наукових журналах з високим імпакт-фактором, а саме: «International Journal of Drug Policy», «International Journal of Law and Psychiatry», «The Lancet» тощо. Таким чином, це свідчить про те, що тематика досліджень щодо травмування, шкоди та збитків у кримінальному законодавстві $€$ актуальною у галузі юриспруденції та регулювання. Результати бібліометричного аналізу дозволили виділити 6 кластерів тематичної спрямованості досліджуваних статей. При цьому найбільші з них об'єднали наступні ключові слова: 1) кримінальне правосуддя, правоохоронна діяльність, охорона здоров'я, політика охорони здоров'я, зменшення шкоди, законодавство про наркотики, контроль над наркотиками, наркоманія, безпритульність, тощо; 2) злочинна поведінка, жертва злочину, підліток, насильство, психічне здоров'я, психічні захворювання, ув'язнений, молодь, з'валтування, поліція тощо; 3) кримінальні аспекти судової практики, кримінальне право, права людини, юридична відповідальність, соціальний контроль, державне регулювання, тощо. На основі виявлених тенденцій у наукових публікаціях, автори прийшли до висновку, що врівноваження трикутників «медичні помилки - злочин освіта», «наркотики - злочин - справедливість» та «аборт -злочин - жінки/діти» $є$ головною тематикою наукових напрацювань щодо дослідження питань травмування, шкоди здоров'ю та збитків у кримінальному праві.

Ключові слова: травма, шкода, збитки, здоров'я людини, кримінальне право, менеджмент, уряд.

Manuscript received: 13.07.2020

(C) The author(s) 2020. This article is published with open access at Sumy State University 